\title{
Fosfohedyfán z opuštěného železnorudného ložiska Hraničná (Slezsko, Česká republika)
}

\author{
Phosphohedyphane from the abandoned iron deposit Hraničná (Silesia, Czech Republic)
}

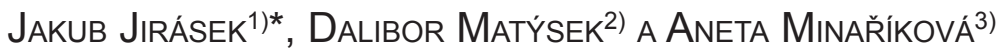 \\ 1)Centrum ENET \& Katedra geologického inženýrství, Hornicko-geologická fakulta, Vysoká škola báňská - Technická \\ univerzita Ostrava, 17. listopadu 15/2172, 70833 Ostrava-Poruba; *e-mail: jakub.jirasek@vsb.cz \\ 2)Institut čistých technologií těžby a užití energetických surovin \& Katedra geologického inženýrství, Hornicko-geologická \\ fakulta, Vysoká škola báňská - Technická univerzita Ostrava, 17. listopadu 15/2172, 70833 Ostrava-Poruba \\ ${ }^{3)}$ Katedra geologického inženýrství, Hornicko-geologická fakulta, Vysoká škola báňská - Technická univerzita Ostrava, \\ 17. listopadu 15/ 2172, 70833 Ostrava-Poruba
}

JiRÁsek J, MatÝsek D, MinaŘíiKová A (2020) Fosfohedyfán z opuštěného železnorudného ložiska Hraničná (Slezsko, Česká republika). Bull Mineral Petrolog 28(1): 44-47 ISSN 2570-7337

\begin{abstract}
Abandoned iron skarn deposit Hraničná is located 16 km NW of Jeseník, Silesia, Czech Republic. It is situated in the Staré Město Crystalline Complex, belt of high grade metamorphic rocks, which are supposed to be a meta-ophiolite of the initial Cambro-Ordovican rifting. The deposit itself is formed by two stratiform magnetite-hematite bodies within the marbles and quartz-rich biotite gneisses. Marbles containing silicates are rich in $\mathrm{Zn}$ and $\mathrm{Pb}$ and give evidence for sedimentary or volcanosedimentary origin of the ore accumulation. We collected several samples at the adit and $+20 \mathrm{~m}$ levels of the mine which yielded phosphohedyphane. The mineral forms irregular aggregates up to $100 \mu \mathrm{m}$ within the calcite-dolomite-magnetite skarn. Its average chemical formula from 7 WDS spots is $\left(\mathrm{Ca}_{2.07} \mathrm{Sr}_{0.03} \mathrm{Ba}_{0.01} \mathrm{Mg}_{0.02} \mathrm{~Pb}_{3.23} \mathrm{Zn}_{0.01}\right.$ $\left.\mathrm{Fe}_{0.09} \mathrm{Al}_{0.01}\right)_{\Sigma 5.47}\left[\left(\mathrm{PO}_{4}\right)_{2.53}\left(\mathrm{AsO}_{4}\right)_{0.03}\left(\mathrm{SO}_{3}\right)_{0.01}\left(\mathrm{SiO}_{4}\right)_{0.24}\right]_{\Sigma 2.81}\left[\mathrm{Cl}_{1.05} \mathrm{~F}_{0.20}\right]_{\Sigma 1.25}$ based on $13 \mathrm{O}+\mathrm{Cl}+\mathrm{F}$. Use of the normalization to $\mathrm{Ca} 1+\mathrm{Ca} 2=5$ and employing the charge balance could lead to the possible presence of $\left(\mathrm{CO}_{3}\right)^{2-}$ up to 0.60 apfu, resp. $3.61 \mathrm{wt} . \% \mathrm{CO}_{2}$; this possible content does not have any effect on mineral classification. It is, therefore, the fifht reported occurrence of this mineral in the territory of the Czech Republic and the Bohemian Massif.
\end{abstract}

Key words: phosphohedyphane, hedyphane group, iron skarn, Staré Město Crystalline Complex, Czech Republic

Obdrženo 14. 1. 2020; prijato 3. 4. 2020

\section{Úvod}

Výzkum pomocí elektronové mikroskopie a vlnově disperzní analýzy přinesl nález nového minerálu pro opuštěné ložisko železných rud Hraničná ve Slezsku. Konkrétně se jedná o fosfohedyfán. Nález pochází ze štolového patra z okrajové části skarnové polohy bohaté magnetitem. Cílem tohoto príspěvku je charakterizovat jeho výskyt, který je pro Českou republiku ojedinělý.

Fosfohedyfán je poměrně nedávno schválený a publikovaný minerál $\mathrm{s}$ ideálním krystalochemickým vzorcem $\mathrm{Ca}_{2} \mathrm{~Pb}_{3}\left(\mathrm{PO}_{4}\right)_{3} \mathrm{Cl}$, náležící do skupiny hedyfánu. Na rozdíl od vápníkem bohatých pyromorfitů je pro něj typické to, že $\mathrm{Ca}$ a $\mathrm{Pb}$ se nacházejí ve dvou různých kationtových pozicích, a pozice $\mathrm{Ca} 2$ je obsazena prakticky výhradně olovem (Kampf et al. 2006).

Lokalizace, stručná historie těžby a mineralogicko-geologické poměry

Ložisko Hraničná se nachází na území dnes zcela zaniklé osady Hraničná (něm. Gränzgrund, Grenzgrund) v katastrálním území obce Petrovice u Skorošic. Portál štoly má GPS souřadnice N $50^{\circ} 18.781^{\prime}$ E $017^{\circ} 01.092^{\prime}$.

Přesné počátky zdejší těžby nejsou známé, ale pravděpodobně se datuji do počátku 2. poloviny 19 . století.
Z tohoto období se dochovalo jen minimum písemných informací, ale odpovídají mu nafárané stařiny a skromné povrchové projevy. Tato těžba pravděpodobně skončila okolo roku 1904 (Lomič 1955, 1956). Druhá etapa těžby železných rud v letech 1960 až 1968 navázala na úspěšný ložiskový průzkum v padesátých letech. Otvírka byla realizována štolou se třemi větracími komíny, úpadnicemi pak do hloubky $125 \mathrm{~m}$ pod úroveň štolového patra. $\mathrm{V}$ této druhé etapě, která skončila vytěžením bilančních zásob ložiska, bylo získáno 173 kt rudy. Dobývací prostor byl zrušen v roce 1973 (Zelinger ed. 1998).

Ložisko se nachází ve staroměstském krystaliniku (dříve též pásmu). Jde o nejvýchodnější část lugika na styku se silesikem. Vytváří pásmo přibližně $40 \mathrm{~km}$ dlouhé a široké 4 - 5 km. Krystalinikum obsahuje zejména silně metamorfované sedimentární horniny, amfibolity s čočkami peridotitů, gabra a syntektonickou intruzi tonalitu. Celé krystalinikum patrně představuje metaofiolitovou zónu počátečního vývoje riftové zóny pozdně kambrického až ordovického stáří (McCann et al. 2008). Ložisko samotné se nachází v litologicky pestré skupině Hraničné (Krut’a, Skácel 1975; Fojt, Krut'a 1976). Jde o stratiformní akumulaci, tvořící dvě polohy Fe-rud v dolomitických mramorech, které jsou obklopeny pararulami, svorovými rulami, leptynity, kvarcity, metalydity a amfibolity. Průměrná mocnost obou poloh kolísá mezi 
0.6 - $0.8 \mathrm{~m}$ a je sledovatelná na vzdálenost približně $500 \mathrm{~m}$ Magnetit-hematitové polohy jsou doprovázeny impregnacemi sulfidů a gahnitu v okolních horninách (Novák et al. 1997). V místech tektonického postižení jsou ložiskové polohy pronikány granitickými pegmatity s draselným živcem bohatým na $\mathrm{Pb}$ (Litochleb 2000). Modelové stárí galenitů z Hraničné bylo určeno na 763 Ma (Petrold, Stehlík 1978). Dřive byla Hraničná interpretována jako skarnové ložisko. Novější práce ukazují na to, že předmetamorfní povaha této rudní akumulace byla velmi pravděpodobně sedimentární nebo hydrotermálně sedimentární (Petrold 1986).

Mineralogií ložiska Hraničná se nověji zaobírali zejména Litochleb (1972, 1975) a Krut'a, Skácel (1975). Z primárních minerálů zde byly popsány (abecedně): aktinolit, allanit, almandin, apatit, biotit, diopsid, dolomit, epidot, flogopit, fluorit, franklinit, gahnit, galenit, grafit, grosulár, chalkopyrit, chlorit, hematit, hercynit, kalcit, klinozoisit, křemen, kyanit, magnetit, markazit, mastek, mikroklin, molybdenit, muskovit, pleonast?, pyrit, pyrhotin, rutil?, serpentin, sfalerit, sillimanit, spinel, staurolit, titanit, tremolit a turmalín. Ze supergenních minerálů titíž autoři uvádějí prítomnost cerusitu, covellinu, limonitu, malachitu a sádrovce.

\section{Metodika výzkumu}

Sledování morfologie dutinové mineralizace proběhlo na leštěných nábrusech i prírodních trhlinách za použití autoemisního elektronového mikroskopu FEI Quanta-650 FEG od firmy FEI. Mikrofotografie byly pořízeny pomocí detektoru zpětně odražených elektronů (BSE) v režimu chemického gradientu.

Chemické složení fosfohedyfánu bylo studováno kvantitativně pomocí elektronového mikroanalyzátoru Cameca SX 100 (Prírodovědecká fakulta MU, Brno, analytik R. Čopjaková) za podmínek: vinově disperzní analýza, napětí $15 \mathrm{kV}$, proud $10 \mathrm{nA}$, průměr svazku elektronů do $6 \mu \mathrm{m}$. Jako standardy byly použity dobře definované homogenní minerály a syntetické fáze: lammerit (As La), albit ( $\mathrm{Na} \mathrm{Ka}), \mathrm{Mg}_{2} \mathrm{SiO}_{4}(\mathrm{Mg} \mathrm{K \alpha})$, wollastonit (Si Ka, Ca $\mathrm{K \alpha})$, fluorapatit $(\mathrm{P} K \alpha)$, andradit ( $\mathrm{Fe} K \alpha)$, vanadinit (V Ka, $\mathrm{Pb} \mathrm{Ma}, \mathrm{Cl} \mathrm{Ka})$, gahnit $(\mathrm{Zn} \mathrm{K \alpha})$, ortoklas (K Ka), topaz ( $\mathrm{F}$ $\mathrm{K \alpha})$, spessartin (Mn Ka), $\mathrm{SrSO}_{4}(\mathrm{Sr} \mathrm{L} \alpha)$, andalusit (Al Ka) a baryt (Ba La). Empirický chemický vzorec byl přepočten na 13 atomů aniontů (kyslík + chlór + fluor).

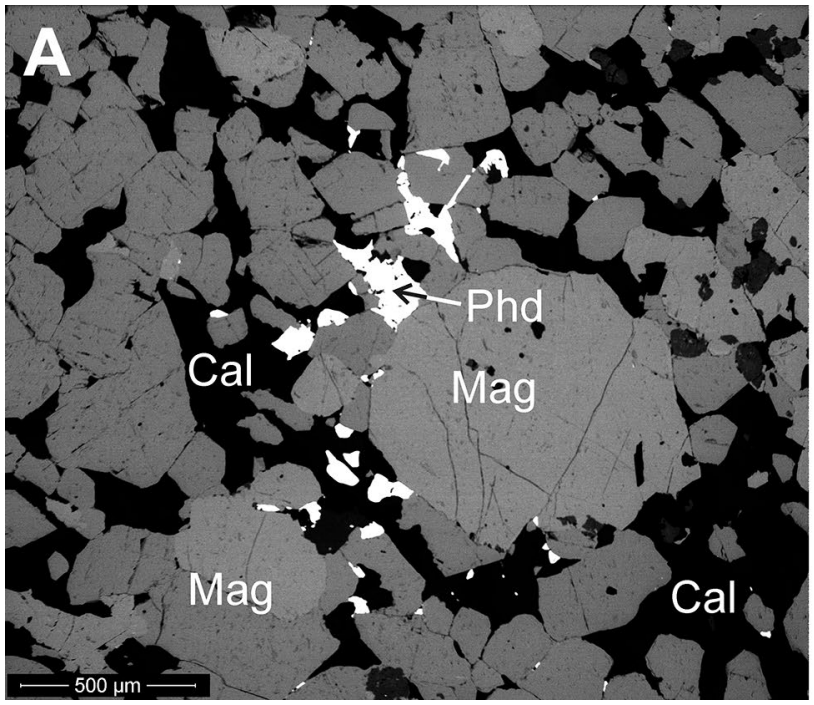

\section{Výsledky}

Fosfohedyfán byl popsán $v$ roce 2006 (Kampf et al. 2006) jako minerál s ideálním složením $\mathrm{Ca}_{2} \mathrm{~Pb}_{3}\left(\mathrm{PO}_{4}\right)_{3} \mathrm{Cl}$. Označení kationtových pozic u něj vychází ze struktury izotypního chlorapatitu (např. Pan, Fleet 2002). Kationtová pozice $\mathrm{Ca} 2 \mathrm{u}$ fosfohedyfánu by měla být plně obsazena $\mathrm{Pb}$, zatímco na pozici Ca1 obsahuje typový materiál $92 \%$ Ca a 8 \% Pb (Kampf et al. 2006).

Studovaný fosfohedyfán byl $v$ Hraničné zjištěn $v$ podobě nehojných laločnatých agregátů s nejdelším rozměrem maximálně $100 \mu \mathrm{m}$ (obr. 1) a je chemicky poměrně homogenní (tab. 1). V kationtových pozicích bylo zjištěno dominantní $\mathrm{Pb}$ (3.12 - 3.37 apfu) a Ca (1.98 - 2.23 apfu). $\checkmark$ pozicích $\mathrm{Ca} 1$ a Ca2 se dále vyskytuje malé množství $\mathrm{Fe}$ (0.17 apfu), Mg (do 0.11 apfu), Sr a Ba (do 0.04 apfu), Mn (do $0.02 \mathrm{apfu}$ ), Na, K (do $0.01 \mathrm{apfu}$ ) a Al (do $0.01 \mathrm{apfu}$ ). $\checkmark$ tetraedrické aniontové pozici byly kromě dominantního P (2.39 - 2.63 apfu) zjištěny Si (do 0.29 apfu), S (do 0.05 apfu), As (do 0.04 apfu) a V (do $0.01 \mathrm{apfu}$ ). Tato zjištění odpovídají známým substitucím v minerálech apatitové superskupiny, popsaným např́klad Panem a Fleetem (2002). $\mathrm{V}$ pozici $\mathrm{X}$ je prevaha $\mathrm{Cl}(0.96-1.12 \mathrm{apfu})$ nad $\mathrm{F}(0.15$ - $0.25 \mathrm{apfu})$. Hodnoty poměru $5 \mathrm{Ca} /(\mathrm{Ca}+\mathrm{Pb})$ a hodnota poměru $\mathrm{P} /(\mathrm{P}+\mathrm{As})$ vynesené $v$ diagramu podle Kampfa et al. (2006) řadí minerál jednoznačně do pole fosfohedyfánu.

Pokus dopočíst obsah $(\mathrm{OH})$ podle postupu publikovaného Ketchamem (2015) skončil zápornými hodnotami, což je dáno mírným nadbytkem jednomocných aniontů a aniontových skupin na pozici $X$ prí mírném nedostatku aniontů $v$ tetraedrické pozici, takže substituce hydroxylové skupiny do této pozice je pravděpodobně minimální. Sumy kationtů v pozicích Ca1 a Ca2 vyšší než 5 při deficitu sumy aniontů by mohly být způsobeny obsahem karbonátové skupiny $v$ aniontu, což je s ohledem na množství dostupného materiálu analyticky obtížně prokazatelné nebo vyvratitelné. Při alternativním přepočtu krystalochemického vzorce na sumu kationtů Ca1 + Ca2 rovnu 5 by pak na základě dopočtení nábojové rovnováhy vycházela teoreticky př́tomná karbonátová skupina v průměru sedmi analýz ve výši cca $0.60 \mathrm{apfu}$, což by odpovídalo $3.61 \mathrm{hm}$. \% $\mathrm{CO}_{2}$. Dopočet $\mathrm{CO}_{2}$ by ovšem vedl k nutnosti zavedení i určitého drobného množství $(\mathrm{OH})^{-}$skupin do pozice $\mathrm{X}$. I přes hypotetický obsah $\mathrm{CO}_{2}$ se ale zcela jistě jedná o fosfohedyfán $\mathrm{s}$ dominancí $\mathrm{PO}_{4}{ }^{3-} \mathrm{v}$ tetraedrických pozicích a $\mathrm{Cl} \vee$ pozici $\mathrm{X}$.

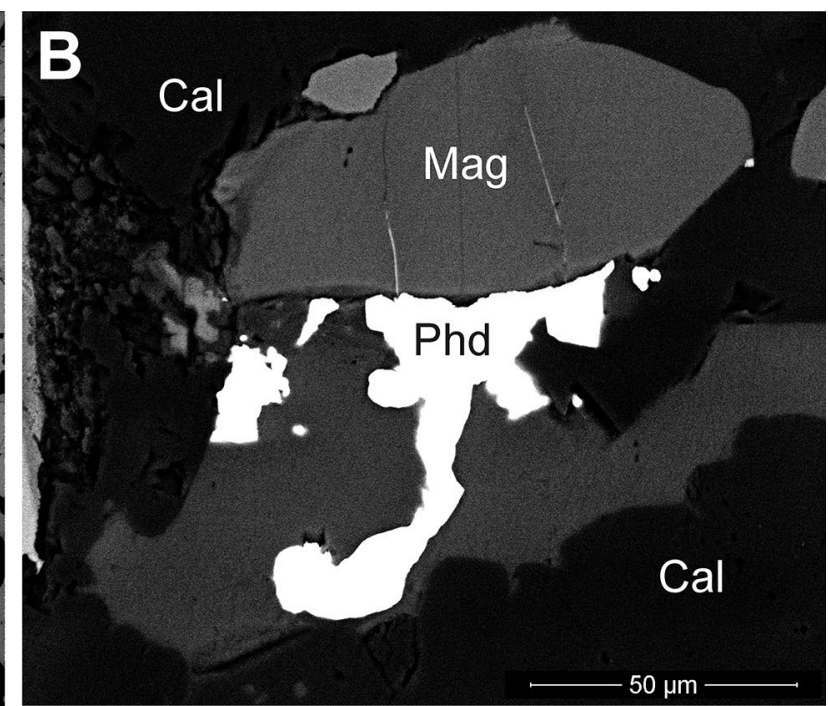

Obr. 1 Agregáty fosfohedyfánu zobrazené ve zpětně odražených elektronech. A - fosfohedyfán (Phd) mezi zrny magnetitu (Mag) společně s kalcitem (Cal), B - laločnatý agregát fosfohedyfánu (Phd). Foto D. Matýsek. 


\section{Diskuse a závěr}

Fosfohedyfán představuje pro území České republiky poměrně vzácný, respektive dosud málo popisovaný minerál. Jeho první popis pochází ze žily Karel u Slivice, kde se vyskytl jako úzké zóny $v$ oscilačně zonálním pyromorfitu (Sejkora et al. 2008). Tenké zóny fosfohedyfánu v pyromorfitu byly zjištěny také v Kosově a Komárovicích v jihlavském rudním revíru (Kocourková et al. 2010) a v jediném vzorku pyromorfitu z haldy Dolu Řimbaba v příbramském polymetalickém revíru (Mráček 2013). Jediný makroskopický nález fosfohedyfánu pochází z Horní Rokynice (Sejkora et al. 2010), ovšem bez dosud publikovaných analytických údajů. Námi popsaný výskyt představuje sběratelsky neatraktivní materiál, kdy minerál má pouze mikroskopické rozměry a je zarostlý $v$ karbonátech mezi zrny oxidů Fe. Vzhledem k polyfázovému vzniku železnorudného ložiska Hraničná je geneze fosfohedyfánu nejistá, ale zjevně je mladší než magnetit a gahnit.

Opuštěné železnorudné ložisko Hraničná představuje stále jednu z nejzajímavějších rudních akumulací české části Slezska. Díky spolku Rychlebská báňsko-historická z.s., který důlní dílo roku 2014 převzal od státního podniku DIAMO, je možné po dohodě nezatopenou část dolu navštívit a provádět další prípadné geologické a mineralogické výzkumy.

$\mathrm{S}$ ohledem na rychlý rozvoj mineralogických metod v posledních desetiletích Ize předpokládat, že systematický průzkum Hraničné by mohl přinést další zajímavé objevy z tohoto největšího železnorudného „skarnu“ v české části Slezska.

Tabulka 1 Chemické složení fosfohedyfánu (hm. \%) a prepočet koeficientů empirického vzorce na 13 aniontů.

\begin{tabular}{|c|c|c|c|c|c|c|c|c|}
\hline & mean & 1 & 2 & 3 & 4 & 5 & 6 & 7 \\
\hline $\mathrm{Na}_{2} \mathrm{O}$ & 0.01 & 0.02 & 0.00 & 0.00 & 0.00 & 0.02 & 0.02 & 0.01 \\
\hline $\mathrm{K}_{2} \mathrm{O}$ & 0.01 & 0.04 & 0.00 & 0.05 & 0.00 & 0.00 & 0.01 & 0.00 \\
\hline $\mathrm{CaO}$ & 10.62 & 11.34 & 10.39 & 11.50 & 10.89 & 10.09 & 10.17 & 9.97 \\
\hline $\mathrm{SrO}$ & 0.26 & 0.23 & 0.27 & 0.20 & 0.34 & 0.25 & 0.33 & 0.18 \\
\hline $\mathrm{BaO}$ & 0.14 & 0.20 & 0.00 & 0.51 & 0.00 & 0.28 & 0.00 & 0.00 \\
\hline $\mathrm{MgO}$ & 0.06 & 0.42 & 0.00 & 0.00 & 0.00 & 0.00 & 0.00 & 0.00 \\
\hline $\mathrm{MnO}$ & 0.02 & 0.00 & 0.00 & 0.10 & 0.05 & 0.01 & 0.00 & 0.00 \\
\hline $\mathrm{PbO}$ & 66.13 & 63.91 & 66.01 & 65.97 & 65.75 & 65.49 & 68.09 & 67.69 \\
\hline $\mathrm{ZnO}$ & 0.08 & 0.12 & 0.00 & 0.11 & 0.08 & 0.25 & 0.00 & 0.00 \\
\hline $\mathrm{FeO}$ & 0.57 & 1.12 & 0.61 & 0.55 & 0.37 & 0.98 & 0.16 & 0.21 \\
\hline $\mathrm{P}_{2} \mathrm{O}_{5}$ & 16.45 & 15.34 & 15.75 & 17.48 & 16.95 & 16.50 & 17.11 & 16.00 \\
\hline $\mathrm{As}_{2} \mathrm{O}_{5}$ & 0.24 & 0.26 & 0.34 & 0.09 & 0.21 & 0.28 & 0.25 & 0.26 \\
\hline $\mathrm{V}_{2} \mathrm{O}_{5}$ & 0.03 & 0.00 & 0.04 & 0.03 & 0.08 & 0.00 & 0.00 & 0.06 \\
\hline $\mathrm{Al}_{2} \mathrm{O}_{3}$ & 0.03 & 0.02 & 0.07 & 0.00 & 0.00 & 0.04 & 0.07 & 0.00 \\
\hline $\mathrm{SO}_{3}^{2}$ & 0.08 & 0.00 & 0.37 & 0.00 & 0.07 & 0.00 & 0.00 & 0.10 \\
\hline $\mathrm{SiO}_{2}^{3}$ & 1.34 & 1.58 & 1.55 & 1.10 & 1.26 & 1.29 & 1.03 & 1.56 \\
\hline $\mathrm{Cl}$ & 3.40 & 3.29 & 3.45 & 3.58 & 3.14 & 3.48 & 3.28 & 3.57 \\
\hline $\mathrm{F}$ & 0.34 & 0.38 & 0.31 & 0.29 & 0.45 & 0.35 & 0.36 & 0.25 \\
\hline$-\mathrm{O}=\mathrm{Cl}+\mathrm{F}$ & 0.91 & 0.90 & 0.91 & 0.93 & 0.90 & 0.93 & 0.89 & 0.91 \\
\hline$\Sigma$ & 98.90 & 97.36 & 98.25 & 100.63 & 98.74 & 98.38 & 100.01 & 98.94 \\
\hline $\mathrm{Na}^{+}$ & 0.003 & 0.006 & 0.000 & 0.000 & 0.001 & 0.006 & 0.008 & 0.003 \\
\hline $\mathrm{K}^{+}$ & 0.003 & 0.008 & 0.000 & 0.011 & 0.001 & 0.000 & 0.003 & 0.000 \\
\hline $\mathrm{Ca}^{2+}$ & 2.067 & 2.223 & 2.039 & 2.167 & 2.098 & 1.973 & 1.976 & 1.975 \\
\hline $\mathrm{Sr}^{2+}$ & 0.027 & 0.025 & 0.029 & 0.020 & 0.036 & 0.026 & 0.035 & 0.019 \\
\hline $\mathrm{Ba}^{2+}$ & 0.010 & 0.015 & 0.000 & 0.035 & 0.000 & 0.020 & 0.000 & 0.000 \\
\hline $\mathrm{Mg}^{2+}$ & 0.016 & 0.114 & 0.000 & 0.000 & 0.000 & 0.000 & 0.000 & 0.000 \\
\hline $\mathrm{Mn}^{2+}$ & 0.004 & 0.000 & 0.000 & 0.015 & 0.007 & 0.002 & 0.000 & 0.000 \\
\hline $\mathrm{Pb}^{2+}$ & 3.233 & 3.163 & 3.256 & 3.123 & 3.182 & 3.218 & 3.323 & 3.270 \\
\hline $\mathrm{Zn}^{2+}$ & 0.011 & 0.017 & 0.000 & 0.014 & 0.010 & 0.034 & 0.000 & 0.000 \\
\hline $\mathrm{Fe}^{2+}$ & 0.086 & 0.171 & 0.093 & 0.081 & 0.055 & 0.150 & 0.024 & 0.032 \\
\hline $\mathrm{Al}^{3+}$ & 0.006 & 0.004 & 0.014 & 0.000 & 0.000 & 0.009 & 0.014 & 0.000 \\
\hline$\Sigma \mathrm{Ca} 1+\mathrm{Ca} 2$ sites & 5.467 & 5.757 & 5.433 & 5.468 & 5.391 & 5.438 & 5.383 & 5.399 \\
\hline $\mathrm{P}^{5+}$ & 2.529 & 2.388 & 2.444 & 2.603 & 2.580 & 2.549 & 2.626 & 2.505 \\
\hline $\mathrm{As}^{5+}$ & 0.027 & 0.029 & 0.038 & 0.009 & 0.023 & 0.031 & 0.028 & 0.030 \\
\hline$V^{5+}$ & 0.002 & 0.000 & 0.003 & 0.002 & 0.007 & 0.000 & 0.000 & 0.005 \\
\hline $\mathrm{S}^{6+}$ & 0.011 & 0.000 & 0.051 & 0.000 & 0.009 & 0.000 & 0.000 & 0.014 \\
\hline $\mathrm{Si}^{4+}$ & 0.243 & 0.291 & 0.285 & 0.193 & 0.227 & 0.235 & 0.187 & 0.289 \\
\hline$\Sigma$ T-site & 2.812 & 2.708 & 2.821 & 2.808 & 2.846 & 2.815 & 2.840 & 2.843 \\
\hline $\mathrm{Cl}^{-}$ & 1.047 & 1.026 & 1.072 & 1.068 & 0.956 & 1.076 & 1.009 & 1.120 \\
\hline$F^{-}$ & 0.195 & 0.220 & 0.179 & 0.159 & 0.253 & 0.204 & 0.208 & 0.146 \\
\hline $\mathrm{O}^{2-}$ & 11.758 & 11.754 & 11.749 & 11.773 & 11.791 & 11.719 & 11.784 & 11.733 \\
\hline$\Sigma X$-site & 13.000 & 13.000 & 13.000 & 13.000 & 13.000 & 13.000 & 13.000 & 13.000 \\
\hline
\end{tabular}




\section{Poděkování}

Vznik tohoto článku byl finančně podpořen grantovými projekty Ministerstva školství, mládeže a tělovýchovy ČR SGS SP2020/79 a využil techniku získanou díky projektům L01404 a L01406 stejného poskytovatele. Zapojená studentka za finanční podporu děkuje dotačnímu programu „Podpora vědy a výzkumu v Moravskoslezském kraji 2019“ (RRC/10/2019) financovanému z rozpočtu Moravskoslezského kraje. Dále děkujeme recenzentům Petru Paulišovi a Martinu Števkovi a editorovi Jiř́mu Sejkorovi za kritické poznámky, které vedly ke zkvalitnění rukopisu.

\section{Literatura}

FoJt B, KRUŤA T (1976) Geologické, mineralogické a ložiskové poměry Rychlebských hor v severozápadním Slezsku. Čas Morav Muz, Vědy přír 61, 7-52

Kampf AR, Steele IM, Jenkins RA (2006) Phosphohedyphane, $\mathrm{Ca}_{2} \mathrm{~Pb}_{3}(\mathrm{PO} 4)_{3} \mathrm{Cl}$, the phosphate analog of hedyphane: Description and crystal structure. Am Mineral 91: 1909-1917

KeTCHAM R (2015) Technical note: Calculation of stoichiometry from EMP data for apatite and other phases with mixing on monovalent anion sites. Am Mineral 100: 1620-1623

Kocourková E, Houzar S, Hrazdil V (2010) Pyromorfit z jihlavského rudního revíru. Acta Mus Morav, Sci geol 95: 105-120

KRUŤA T, SKÁCEL J (1975) Ložisko Hraničná v Rychlebských horách ve Slezsku. Čas Morav Muz, Vědy prír 60: $33-56$

LıTOCHLEB J (1972) Gahnit z magnetitového ložiska Hraničná ve Slezsku. Čas Mineral Geol 17: 431-434

LıTOCHLEB J (1975) Magnetitové a sulfidické zrudnění na ložisku Hraničná. Čas Slez Muz, Sci Nat 24: 149-167

LıToCHLEB J (2000) Mineralogie magnetitového ložiska Hraničná v Rychlebských horách. Minerál 8: 301-308

Lomıč V (1955) Soupis historických podkladů pro prospekční práce na lokalitě Hraničná. MS, Ústav pro výzkum rud \& Český báňský archiv, Kutná Hora
Lomıč V (1956) Závěrečná zpráva o archivním výzkumu na lokalitě Hraničná. MS, Ústav pro výzkum rud \& Český báňský archiv Kutná Hora

McCann T, SKompski S, Poty E, Dusar M, Vozárová A, Schneider J, Wetzel A, Krainer K, Kornpihl K, Schäfer A, Krings M, Oplustil S, TAit J (2008) Carboniferous. In McCann T (ed.) The geology of Central Europe Volume 1: Precambrian and Palaeozoic: 411-529. The Geological Society, London

MRÁČEK M (2013) Mineralogie pyromorfitů z příbramského rudního revíru. MS, Bakalářská práce, PřF MU Brno

NovÁK M, HouzAR S, ŠREIN V (1997) Gahnite-bearing marbles and their significance for regional classification of the eastern part of the Bohemian Massif. J Czech Geol Soc 42: 33-40

PAN Y, FLEET ME (2002) Composition of the apatite-group minerals: substitution mechanisms and controlling factors. Rev Mineral Geochem 48: 13-49

Pertold Z (1986) Stratiformní ložiska orlicko-kladské klenby. In Bernard JH, Pouba Z (eds.) Rudní ložiska a metalogeneze československé části Českého masívu: 240-242. Ústřední ústav geologický, Praha

Pertold Z, Stehlík E (1978) Modelové stáŕí stratiformních galenitů Českého masívu na základě izotopického složení olova. Sborník Korelace proterozoických a paleozoických stratiformních ložisek V.: 195-208. Ústav geologických věd Přírodovědecké fakulty Univerzity Karlovy, Praha

SeJKora J, BuREš B, ŠKoda R (2010) Nové nálezy supergenních minerálů na rudním ložisku Horní Rokytnice v Krkonoších. Minerál 18: 108-115

Sejkora J, Litochleb J, Strnad J, Kubica J (2008) Supergenní mineralizace slivického pásma (žíla Karel) jv. od Př́brami, Česká republika. Bull mineral-petrolog Odd Nár Muz (Praha) 16: 1-10

ZeLINGER O (ed.) (1998) RD Jeseník 1958-1998: 1-213, RD Jeseník, Jeseník 